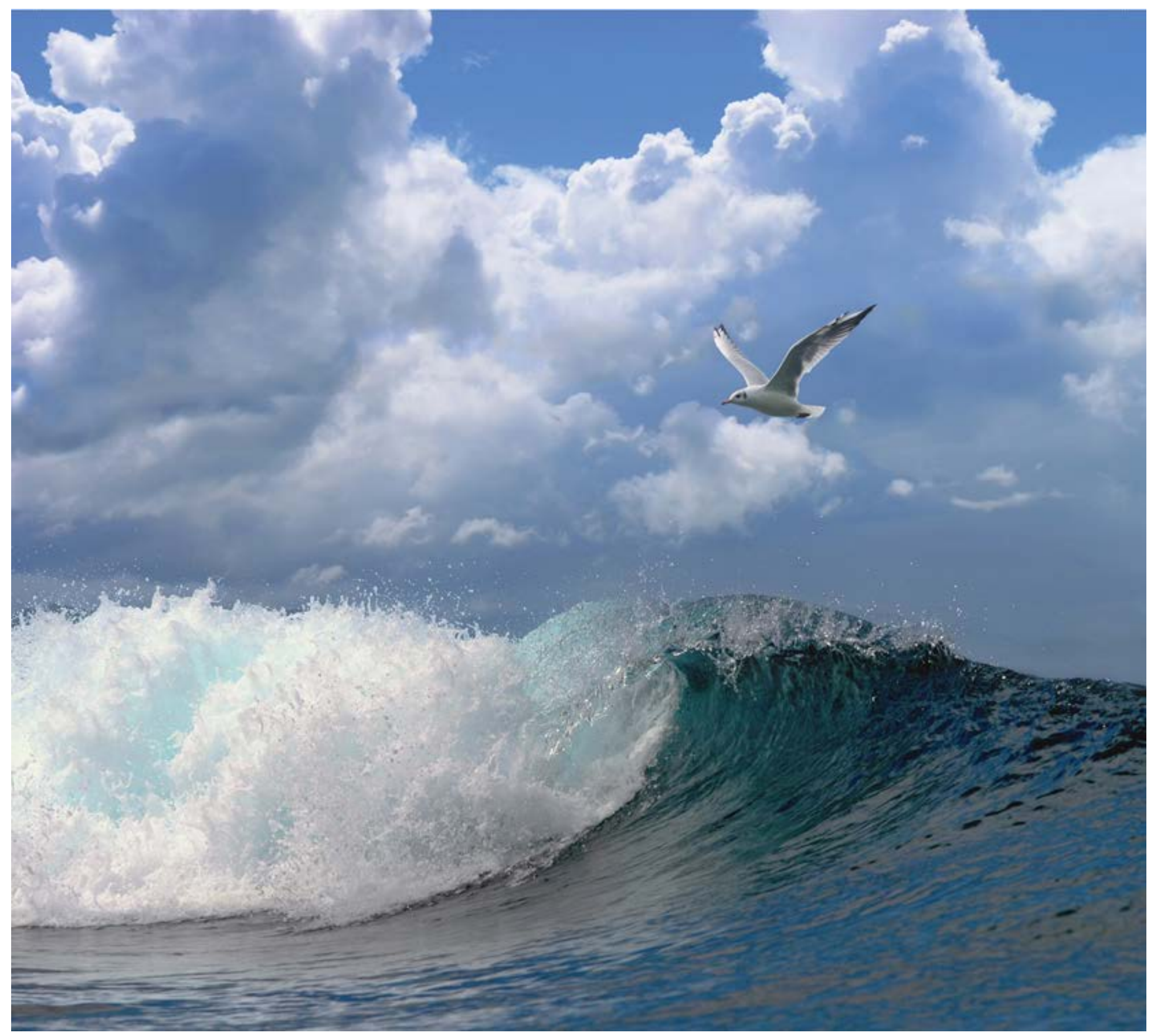

\title{
Buitendijks recreëren ter hoogte van St. Pieterspolder, gemeente Reimerswaal
}




\section{Buitendijks recreëren ter hoogte van St. Pieterspolder, gemeente Reimerswaal}

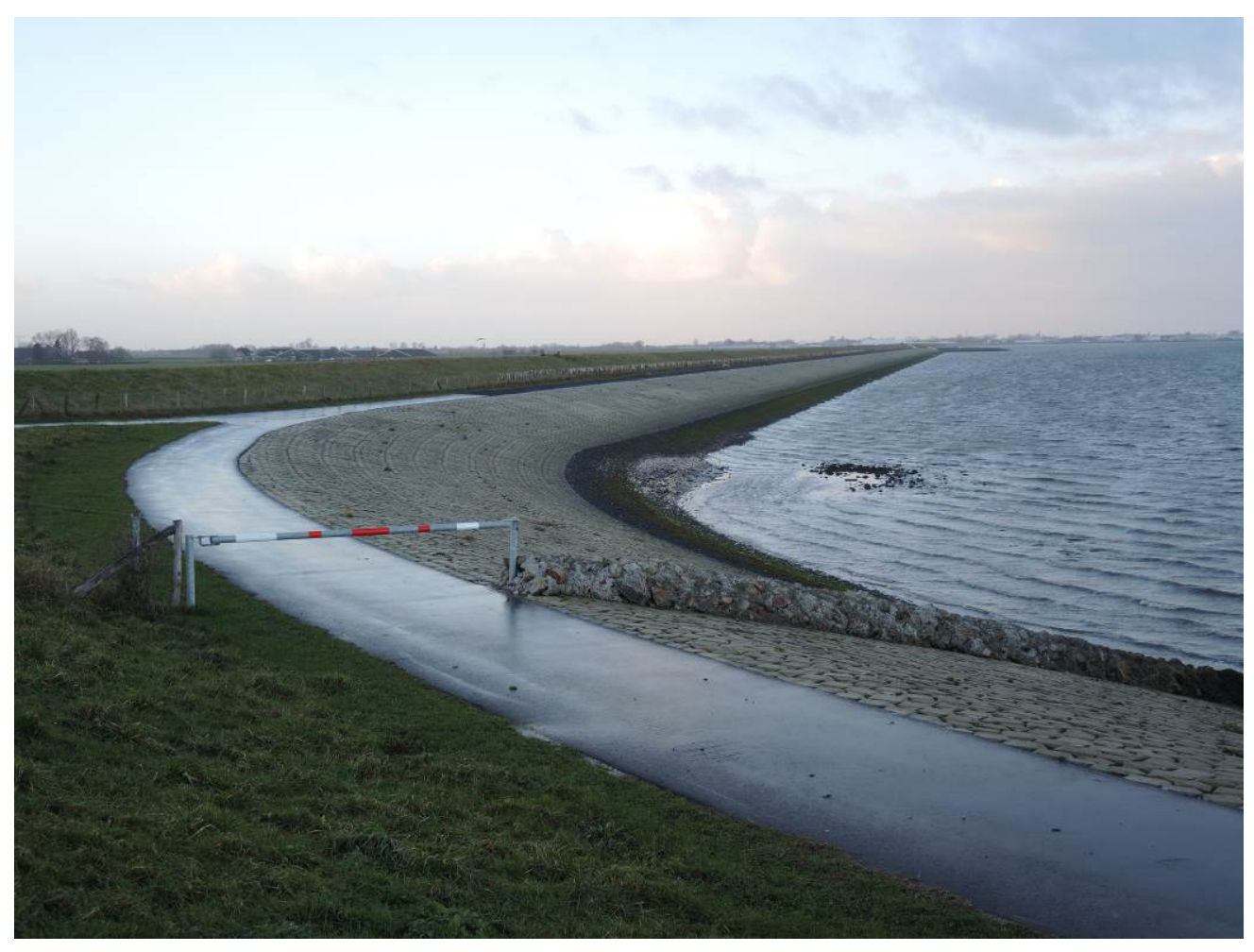

Auteurs:

Tom Ysebaert, Jeroen Wijsman

Publicatiedatum: April 2017 
Ysebaert T, Wijsman J.W.M. 2017. Buitendijks recreëren ter hoogte van St. Pieterspolder. Wageningen Marine Research Wageningen UR (University \& Research centre), Wageningen Marine Research rapport C033/17. 23 blz.

Keywords: hoogwatervluchtplaats, Natura 2000, steltlopers, buitendijks, recreatie

Opdrachtgever: Gemeente Reimerswaal

Postbus 70

4416 ZH Kruiningen

Dit rapport is gratis te downloaden van https://doi.org/10.18174/412724.

Wageningen Marine Research verstrekt geen gedrukte exemplaren van rapporten.

Wageningen Marine Research Wageningen UR is ISO 9001:2008 gecertificeerd.

Foto omslag: Tom Ysebaert

(c) 2017 Wageningen Marine Research Wageningen UR

Wageningen Marine Research, onderdeel van Stichting Wageningen Research KvK nr. 09098104,

IMARES BTW nr. NL 8113.83.696.B16

Code BIC/SWIFT address: RABONL2U IBAN code: NL 73 RABO 0373599285
De Directie van Wageningen Marine Research is niet aansprakelijk voor gevolgschade, noch voor schade welke voortvloeit uit toepassingen van de resultaten van werkzaamheden of andere gegevens verkregen van Wageningen Marine Research opdrachtgever vrijwaart Wageningen Marine Research van aanspraken van derden in verband met deze toepassing.

Dit rapport is vervaardigd op verzoek van de opdrachtgever hierboven aangegeven en is zijn eigendom. Niets uit dit rapport mag weergegeven en/of gepubliceerd worden, gefotokopieerd of op enige andere manier gebruikt worden zonder schriftelijke toestemming van de opdrachtgever. 


\section{Inhoud}

$\begin{array}{ll}\text { Samenvatting } & 4\end{array}$

$1 \quad$ Inleiding 5

1.1 Achtergrond 5

1.2 Aanleiding 6

$\begin{array}{lll}1.3 & \text { Onderzoeksvraag } & 7\end{array}$

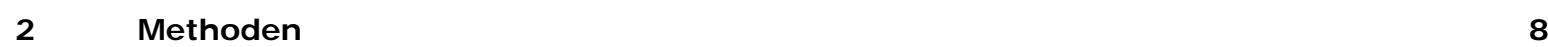

2.1 MWTL hoogwatertellingen $\quad 8$

2.2 Veldbezoeken 9

3 Resultaten $\quad 10$

$\begin{array}{lll}3.1 & \text { Een korte situatieschets } & 10\end{array}$

3.2 Watervogeltellingen 11

3.2.1 Belang St. Pieterspolder voor watervogels 11

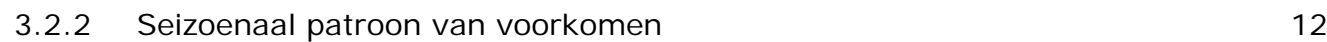

$\begin{array}{lll}3.3 & \text { Veldbezoeken } & 12\end{array}$

$\begin{array}{lll}3.4 & \text { Broedvogels } & 15\end{array}$

$4 \quad$ Conclusies en aanbevelingen 16

$5 \quad$ Kwaliteitsborging $\quad 20$

$\begin{array}{ll}\text { Literatuur } & 21\end{array}$

$\begin{array}{ll}\text { Verantwoording } & 22\end{array}$ 


\section{Samenvatting}

In de Gemeente Reimerswaal bevindt zich een dijktracé langsheen de St. Pieterspolder en Nieuw Olzendepolder waar buitendijks niet mag worden gefietst. Het dijktracé beslaat een lengte van ca 4 $\mathrm{km}$ en ligt ten zuidoosten van Yerseke. Het dijktraject is van belang als hoogwatervluchtplaats voor watervogels. Dat is de reden dat dit dijktracé niet opengesteld is als doorgaand fietspad. De Gemeente Reimerswaal heeft Wageningen Marine Research gevraagd advies uit te brengen over de mogelijkheden voor het buitendijks fietsen langs de St. Pieterspolder - Nieuw Olzendepolder waarbij de natuurfuncties worden gerespecteerd. Ten behoeve van dit advies zijn MWTL hoogwater telgegevens van het dijktracé verzameld en geanalyseerd om het belang van het gebied na te gaan voor de Natura 2000 kwalificerende soorten voor de Oosterschelde, met een nadruk op de steltlopers en eenden/ganzen. Tevens zijn een aantal veldbezoeken uitgevoerd om de situatie ter plaatse te onderzoeken en te kunnen beoordelen.

Het buitendijkse dijktracé langsheen de Sint Pieterspolder en Nieuw Olzendepolder heeft een belangrijke functie als hoogwatervluchtplaats voor een aantal soorten steltlopers en eendachtigen. Met name Scholekster, Wulp, Tureluur, en in mindere mate Steenloper gebruiken de buitendijkse zijde van de zeedijk langs de Nieuw Olzendepolder en de St. Pieterspolder als hoogwatervluchtplaats. Ook Rotganzen en eenden als Wilde Eend, Pijlstaart en Smient gebruiken de dijk als hoogwatervluchtplaats. De grootste aantallen komen voor in de doortrekperiodes en de winter. In de periode april tot en met augustus zijn de aantallen in het gebied laag. De schelpen- en puinstrandjes langs het dijktracé vormen een potentieel geschikt habitat voor kustbroedvogels als de Bontbekplevier.

Buitendijks recreëren langs dit dijktracé leidt tot verstoring van de vogels die hier tijdens hoog water verblijven (overtijen). Dit is duidelijk vastgesteld tijdens de veldbezoeken. Het zondermeer jaarrond openstellen van dit dijktracé voor fietsers is daarom niet aan te bevelen. Wel is een ruimtelijke en temporele zonering mogelijk, welke kan leiden tot een optimalere benutting van dit dijktracé, met versterking van de natuurwaarde en de recreatie. Dit houdt in dat bepaalde trajecten volledig ontoegankelijk worden gemaakt (voor alle vormen van recreatie), en bepaalde trajecten alleen toegankelijk worden gemaakt voor wandelaars en fietsers gedurende de zomerperiode (tussen 1 april en 1 oktober). Een voorstel tot ruimtelijke zonering wordt gemaakt in hoofdstuk 4 van het rapport (Figuur 4-2, Figuur 4-3 en Figuur 4-4). Naast infrastructurele aanpassingen zijn informatie, educatie, handhaving en monitoring/evaluatie hierbij belangrijke onderdelen. 


\section{$1 \quad$ Inleiding}

\section{$1.1 \quad$ Achtergrond}

De Oosterschelde is een Nationaal Park en beschermd als Natura 2000-gebied (Ministerie van Infrastructuur en Milieu | Rijkswaterstaat, 2016). Het Natura 2000-gebied Oosterschelde staat gedeeltelijk in open verbinding met de Noordzee, waardoor er zoute invloed en getijdenwerking aanwezig is: buitendijks liggen droogvallende slikken en platen en schorren met zilte vegetatie, ondieptes en (diepe) geulen. Binnendijks komen zilte graslanden en inlagen voor. De Oosterschelde is als onderdeel van de Deltawateren van grote internationale betekenis voor vogels. Het gebied vormt een zeer belangrijk leefgebied voor kustbroedvogels en is voor trekvogels een onmisbare schakel als ruigebied, tussenstop of overwinteringsgebied om te foerageren en rusten. Naast de rijke natuur kent de Oosterschelde een groot aantal gebruiksfuncties zoals vaarweg, recreatievaart, zwemwater, stranden oeverrecreatie, onderwatersport, kitesurfen, sportvisserij, beroepsvisserij, luchtvaart, natuurbeheer en onderzoeks- en monitoringsactiviteiten (Ministerie van Infrastructuur en Milieu | Rijkswaterstaat, 2016).

Recreatie op en langs de dijken (wandelen, fietsen, paardrijden, sportvissen) kan leiden tot verstoring van broedvogels, rustende vogels, en overtijende vogels op hoogwatervluchtplaatsen (HVP's) die zich op de dijk bevinden, alsmede verstoring van de op de slikken en platen foeragerende vogels. Het bevoegd gezag (Provincie Zeeland) heeft mitigerende maatregelen ingesteld voor recreatie op dijken en aangrenzende buitendijkse gebiedsdelen, inclusief strandjes. Eén van die maatregelen houdt in dat enkele onderhoudswegen op de primaire keringen langs de Oosterschelde zijn afgesloten voor doorgaand fietsverkeer (Ministerie van Infrastructuur en Milieu | Rijkswaterstaat, 2016) (Figuur 1-1). Ze blijven wel toegankelijk voor kleinschalige recreatie via de aanwezige dijkovergangen zoals ze dat ook waren voorafgaand aan de dijkversterkingswerkzaamheden van het Projectbureau Zeeweringen. De trappen (dijkovergangen) langs deze trajecten zijn tevens op de kaart weergegeven. De beperking voor doorgaande fietsroutes wordt niet alleen gerealiseerd via afgesloten overgangen maar zijn vaak ook opgelegd door een bepaalde uitvoering van het onderhoudspad, d.m.v. een bekleding die fietsen ontmoedigt.

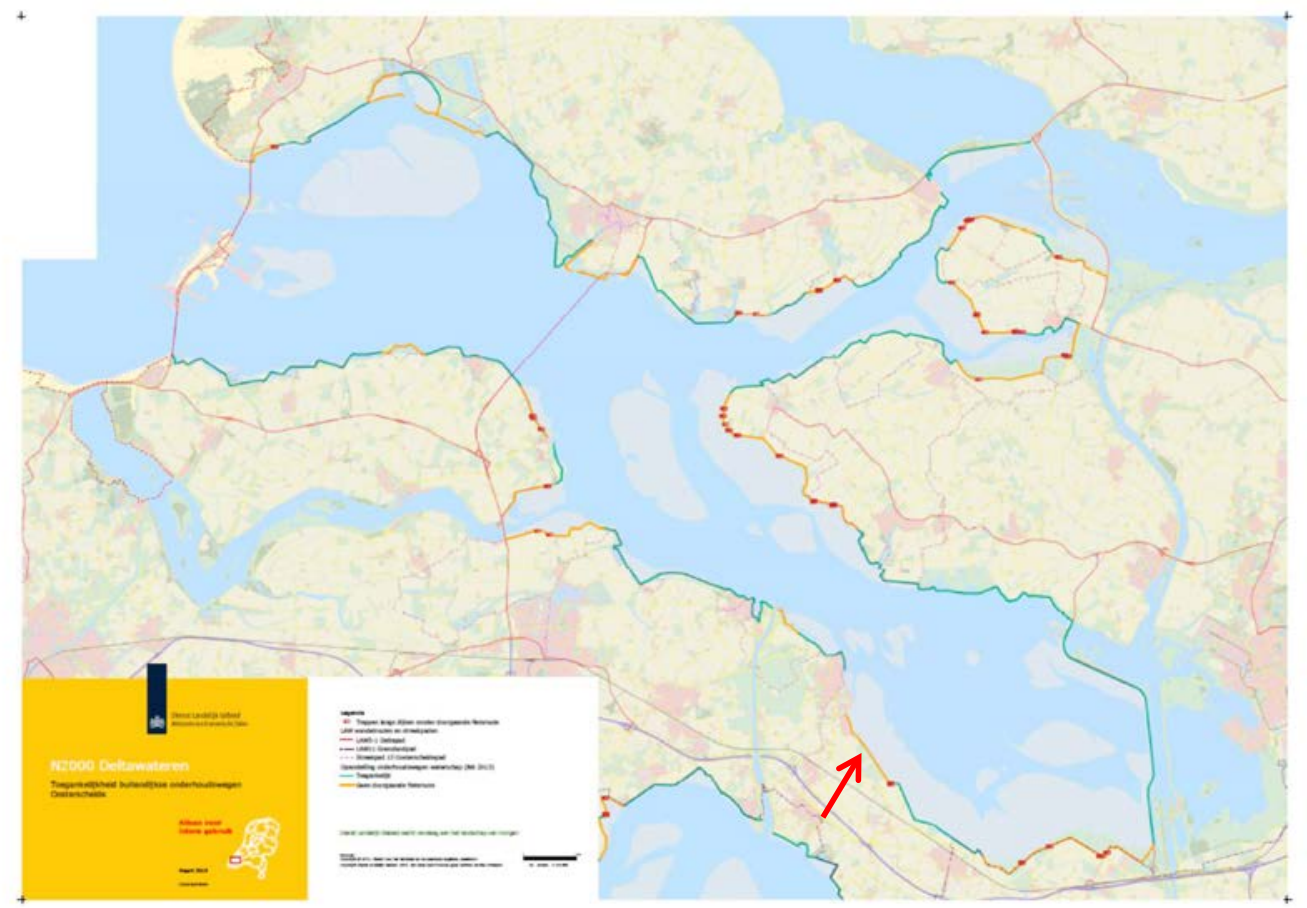

Figuur 1-1 Dijkvakken waar doorgaande fietsroutes zijn afgesloten (oranje lijnen). De dijkovergangen op deze trajecten zijn aangegeven met de rode stippen. De rode peil duidt het dijktracé langs de St. Pieterspolder aan. De blauwe lijnen geven weer waar buitendijks wel kan gefietst worden. (bron: Ministerie van Infrastructuur en Milieu I Rijkswaterstaat, 2016). 


\subsection{Aanleiding}

In de Gemeente Reimerswaal bevindt zich een dijktracé langs de St. Pieterspolder en Nieuw Olzendepolder waar buitendijks niet mag worden gefietst (Figuur 1-1 en, in meer detail, Figuur 1-2). Het dijktracé beslaat een lengte van ca 4 km en ligt ten zuidoosten van Yerseke. Op vraag van bewoners en recreanten wil de Gemeente Reimerswaal nagaan wat de mogelijkheden zijn voor buitendijks fietsen op dit traject. De Gemeente is zich bewust van het belang van rust voor de overtijende vogels bij de St. Pieterspolder, maar heeft Wageningen Marine Research gevraagd de situatie te onderzoeken en na te gaan of er toch mogelijkheden zijn om op dit traject buitendijks te recreëren zonder de natuurfunctie te schaden. Het tracé grenst aan een uitgestrekt slikkengebied in de Kom van de Oosterschelde. De slikken zijn belangrijk voor foeragerende vogels en de dijk en binnendijkse landbouwgronden fungeren als rustgebied (hoogwatervluchtplaats) voor overtijende vogels. In het slik voor de oever liggen voormalige oesterputten en het verdronken dorp Tolsende (archeologisch monument). Verder uit de kust ligt de verdronken stad Reimerswaal. Aan de dijk ligt een voormalig landbouwhaventje (cultuurhistorisch monument) dat recent is gerestaureerd.

Het dijktraject is van belang voor watervogels. Dat is in 2005 vastgesteld in het rapport "Integrale beoordeling van effecten van dijkverbetering op de natuurwaarden van de Oosterschelde" (Schouten et al. 2005). Dat is de reden dat dit dijktracé niet is opengesteld als doorgaand fietspad. Aanpassing van de bekleding van de onderhoudsweg, waardoor fietsen aantrekkelijker wordt, moet eerst aan bevoegd gezag worden voorgelegd zodat kan worden geborgd dat dit niet leidt tot significante verstoring. De komende zes jaar wordt dan via monitoring bepaald of deze maatregel voldoende rust garandeert voor vogels langs de dijken (hoogwatervluchtplaatsen en broedgebieden) (Ministerie van Infrastructuur en Milieu | Rijkswaterstaat, 2016).

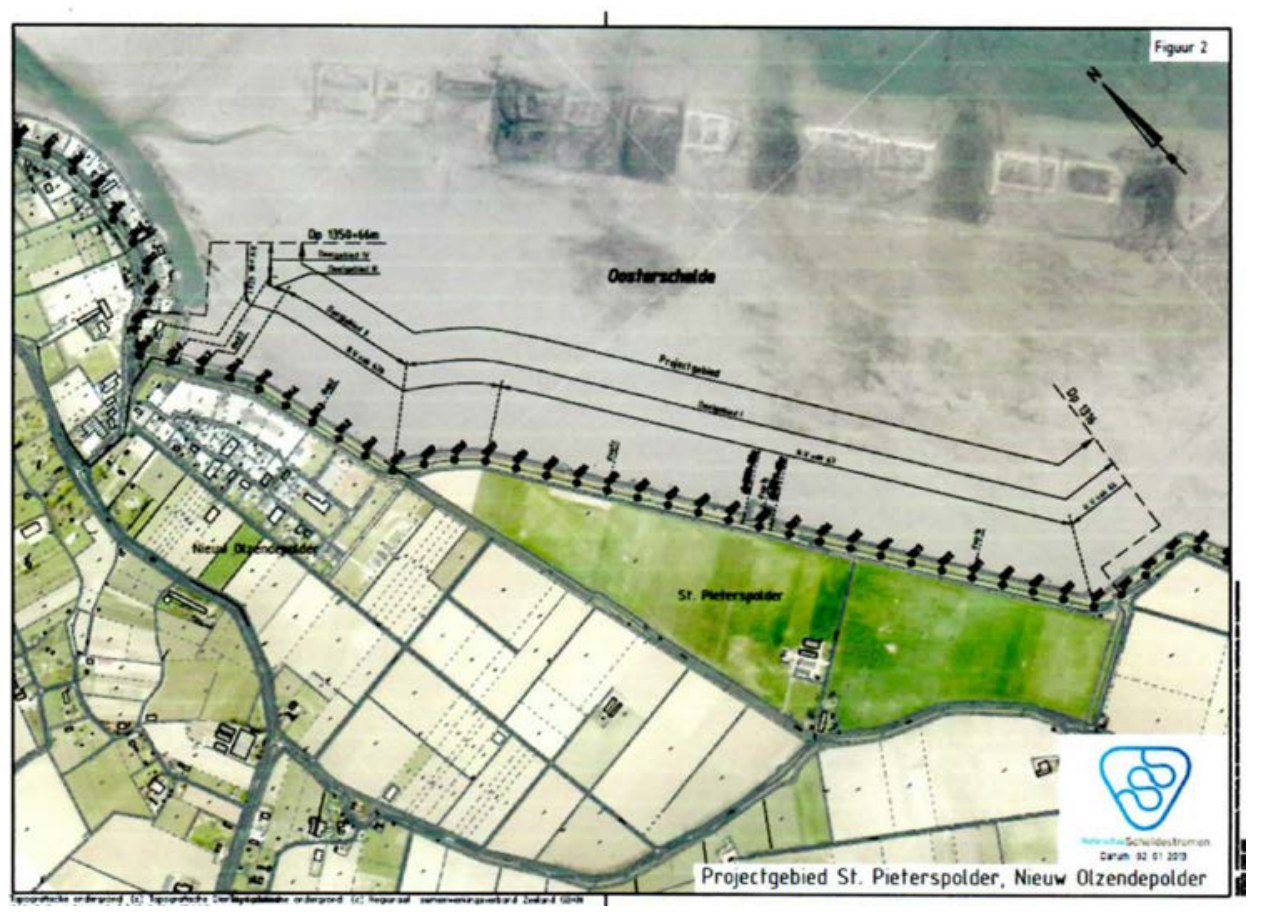

Figuur 1-2. Het traject nabij de Sint Pieterspolder en Nieuw Olzendepolder (gemeente Reimerswaal) dat is afgesloten voor doorgaand fietsverkeer. 


\subsection{Onderzoeksvraag}

De Gemeente Reimerswaal heeft Wageningen Marine Research gevraagd advies uit te brengen over de mogelijkheden om langs de St. Pieterspolder - Nieuw Olzendepolder buitendijks te kunnen fietsen. Dit is momenteel niet toegestaan. Om de gemeente Reimerswaal te kunnen adviseren in dit dossier, en eventuele mitigerende maatregelen voor te stellen, heeft Wageningen Marine Research volgende activiteiten uitgevoerd:

1. Verzamelen en analyseren van MWTL hoogwater telgegevens van het studiegebied en het belang hiervan schetsen in vergelijking met de aantallen in de gehele Oosterschelde.

Besproken worden de Natura 2000 kwalificerende soorten voor de Oosterschelde met een nadruk op de steltlopers en eenden/ganzen.

2. Een aantal veldbezoeken om de situatie ter plaatse te onderzoeken en te beoordelen. 


\section{$2 \quad$ Methoden}

Ten behoeve van het advies aan de gemeente Reimerswaal is een analyse uitgevoerd van bestaande data en een aantal veldbezoeken ter plaatse uitgevoerd.

\section{$2.1 \quad$ MWTL hoogwatertellingen}

In en rondom de grote wateren, ofwel watersystemen, van de Zoute Delta (o.a. Voordelta, Grevelingenmeer, Oosterschelde, Veerse Meer en Westerschelde) worden sinds 1978 maandelijks tellingen verricht. De watervogeltellingen worden vanaf 1990 verricht in het kader van het Biologisch Monitoringprogramma van de Zoute Rijkswateren. Dit is een onderdeel van MWTL (Monitoring Waterstaatkundige Toestand des Lands), uitgevoerd door of in opdracht van de Centrale Informatievoorziening van Rijkswaterstaat. Binnen deze watersystemen zijn veel kleine teltrajecten gedefinieerd, die al sinds het begin van de tellingen worden gebruikt. De tellingen in de getijdenwateren worden uitgevoerd tijdens hoogwater, wanneer vogels die met laagwater foerageren op de drooggevallen slikken en platen, zich verzamelen op hoogwatervluchtplaatsen (HVP's), zie bijv. Arts et al. (2016). De meeste tellingen gebeuren wanneer het hoogwater rond de middag valt. De hoogwatertellingen worden vooral uitgevoerd om een beeld te krijgen van de functie van de grote wateren als foerageergebied. De vogels die op een bepaalde hoogwatervluchtplaats worden waargenomen kunnen worden toegedeeld aan een bijbehorend deelgebied van het watersysteem. Vogelgegevens voor de gehele Oosterschelde en specifiek voor het telgebied OS640 (Yerseke Tolseinde, Figuur 2-1) zijn opgevraagd bij Rijkswaterstaat. De zeedijk van de St. Pieterspolder en de Nieuw Olzendepolder liggen binnen het telgebied OS640. Het telgebied OS640 wordt verder in dit rapport telgebied St. Pieterspolder genoemd.

Een telseizoen loopt van juli tot en met juni, waarbij het jaar verwijst naar de start van het telseizoen; 2013 staat bijvoorbeeld voor juli 2013 t/m juni 2014. Vanaf maart 2013 (telseizoen 2012/2013) is het telprogramma gewijzigd in de Oosterschelde: in zes maanden van het jaar worden niet alle telgebieden meer geteld, maar alleen een aantal steekproefgebieden. Deze steekproefgebieden maken $20 \%$ uit van het totaal aantal telgebieden in het Deltagebied (Arts et al., 2016).

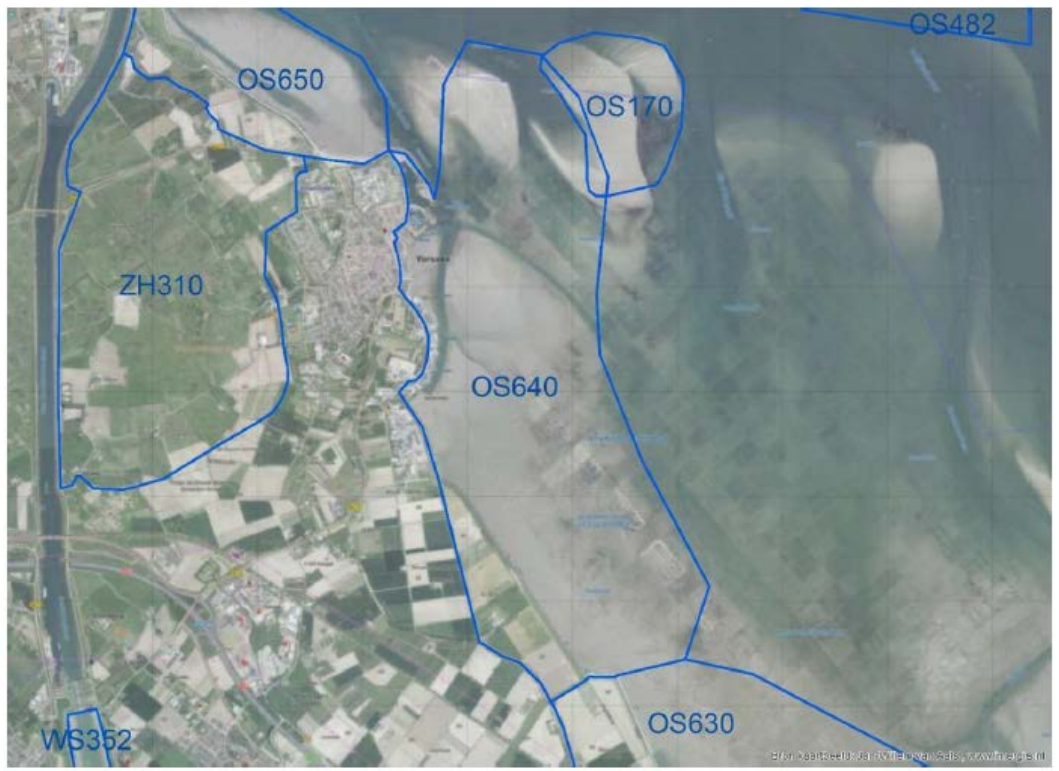

Figuur 2-1. Telgebied St. Pieterspolder (OS640): Yerseke - Tolseinde. 
De Oosterschelde is van groot belang voor watervogels in het Deltagebied en in Nederland. In de Oosterschelde komen 16 soorten steltlopers, 13 soorten eenden, ganzen en zwanen, en 7 soorten viseters voor waarvoor een instandhoudingsdoelstelling is geformuleerd in de Oosterschelde (Ministerie van Infrastructuur en Milieu | Rijkswaterstaat, 2016). In dit rapport worden de tellingen van het traject waarbinnen de Zeedijk van de St Pieterspolder ligt gebruikt. Om het belang aan te geven van de watervogels in dit traject worden de aantallen vergeleken met de aantallen in de hele Oosterschelde. Hiervoor is de meest recente periode onderzocht: 2010/2011 - 2014/2015. Naast jaargemiddelden is ook gekeken naar het voorkomen van de soorten door het jaar heen. Tevens wordt verwezen naar een studie uitgevoerd door Delta Project Management in opdracht van Rijkswaterstaat Zee en Delta die het belang van het studiegebied voor watervogels heeft onderzocht (Arts 2015).

\subsection{Veldbezoeken}

Er zijn vier veldbezoeken uitgevoerd om de situatie ter plaatse te bekijken. Op volgende data is het gebied tijdens hoogwater overdag bezocht:

- 28 november 2016

- 29 november 2016

- 2 december 2016

- 4 januari 2017 


\section{Resultaten}

\subsection{Een korte situatieschets}

Vanuit Yerseke kan men vanaf de Molenpolderweg de Olzendepolderweg betreden (Figuur 3-1). Een verkeersbord duidt aan dat het om een doodlopende weg gaat die niet toegankelijk is voor gemotoriseerde voertuigen. Enkele honderden meters verder komt men bij een splitsing waarbij zowel de dijkovergang (geasfalteerd) als de binnendijkse weg (kiezelweg) afgesloten zijn met een bareel. De dijkovergang kan men met en fiets niet betreden, om de bareel binnendijks kan men heen met een fiets. Bovenop de dijk bij de dijkovergang staat een bord: Kwetsbaar gebied - Verboden toegang op drooggevallen slik - Niets beschadigen of verontrusten (Figuur 3-1). Verder staan hier geen verbodstekens dat men hier niet mag fietsen of wandelen.

De binnendijkse weg gaat wat verder over in een geasfalteerde weg, waar de Olzendepolderweg overgaat in de Schelpkreek. Aan de verbinding met de Sint Pieterspolderweg bevindt zich een tweede dijkovergang, die leidt naar het oude landbouwhaventje (Figuur 3-1). Ook bij deze dijkovergang bevindt zich een bareel en staat een bord: Eigen weg - Toegang op eigen risico (Waterschap Scheldestromen). Ook hier staan verder geen verbodstekens dat men hier niet mag fietsen of wandelen. Op het einde van de Schelpkreek, nabij de Nieuwlandseweg, is er een dijkovergang naar het buitendijkse fietspad dat zich naar het oosten uitstrekt. Hier staat een informatiebord dat uitleg geeft over het fietsnetwerk langs de Oosterschelde en het belang van het afsluiten van bepaalde trajecten (Figuur 3-1). Een bareel op het fietspad verhindert verder buitendijks fietsen richting Yerseke. Buitendijks bevindt zich over het gehele tracé een onderhoudspad met een bekleding die fietsen ontmoedigt. De foto's geven een impressie van de huidige situatie (Figuur 3-1).
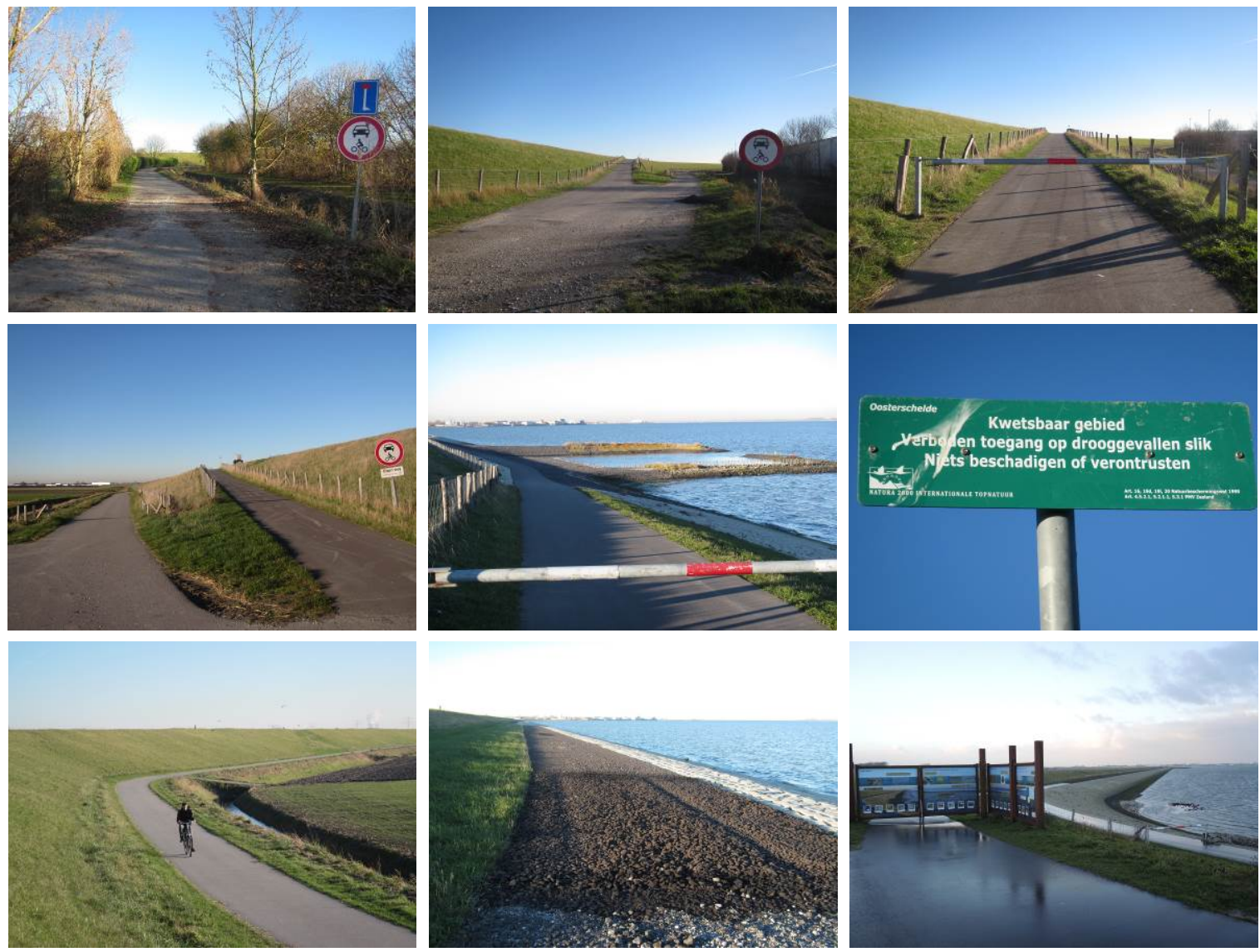

Figuur 3-1. Situatieschets van de huidige situatie langsheen het traject Olzendepolderweg Schelpkreek (Foto's: Tom Ysebaert). 


\subsection{Watervogeltellingen}

\subsubsection{Belang St. Pieterspolder voor watervogels}

Op basis van de MWTL hoogwatertellingen kan gesteld worden dat het telgebied St. Pieterspolder (OS640) van groot belang is voor een aantal steltlopers: Steenloper, Tureluur, Wulp en Scholekster (Tabel 3-1). Deze soorten overtijen in hoofdzaak op de zeedijk van de Nieuw Olzendepolder en de St. Pieterspolder (zie ook Arts 2015). Alleen voor de Steenloper vormen de haven van Yerseke en de kades langs de Korringaweg de belangrijkste hoogwatervluchtplaatsen (Arts 2015, pers. observ.). Wulp en Scholekster gebruiken ook de binnendijkse weilanden en akkers als hoogwatervluchtplaats, vaak wordt hier ook nog gefoerageerd (Arts 2015, pers. observ.).

Eendachtigen zoals de Rotgans, Bergeend, Wilde Eend en Pijlstaart komen ook met hoogwater richting de zeedijk maar zitten dan meer verspreid langs de dijk. De Rotgans komt bij hoogwater vooral voor op de binnendijkse landbouwgronden (pers. observ.). De Brilduiker en viseters zitten op het open water voor de zeedijk (Arts 2015). De overige kwalificerende vogelsoorten komen in veel kleinere aantallen voor in het telgebied St. Pieterspolder en vertegenwoordigen minder dan één percent van de vogels in de Oosterschelde.

Tabel 3-1. Seizoensgemiddelde (periode 2010/2011 - 2014/2015) voorkomen van een aantal relevante soorten in de Oosterschelde, telgebied St. Pieterspolder (OS640) en het aandeel (\%) van het telgebied OS640 ten opzichte van de gehele Oosterschelde.

\begin{tabular}{lccc}
\hline & Oosterschelde & OS640 & $\%$ \\
\hline Steltlopers & & & \\
Scholekster & 20298 & 924 & 4,6 \\
Steenloper & 801 & 429 & 53,5 \\
Tureluur & 1298 & 213 & 16,4 \\
Wulp & 12169 & 809 & 6,6 \\
Eendachtigen & & & \\
Rotgans & 6636 & 880 & 13,3 \\
Bergeend & 1667 & 25 & 1,5 \\
Brilduiker & 226 & 97 & 42,9 \\
Pijlstaart & 384 & 5 & 1,3 \\
Wilde eend & 5016 & 233 & 4,6 \\
Viseters & & & \\
Aalscholver & 334 & 18 & 5,4 \\
Fuut & 282 & 27 & 9,6 \\
Geoorde fuut & 252 & 82 & 32,5 \\
Middelste zaagbek & 369 & 33 & 8,9 \\
\hline
\end{tabular}




\subsubsection{Seizoenaal patroon van voorkomen}

De belangrijkste steltlopers in het telgebied St. Pieterspolder zijn er met name in de winterperiode (Figuur 3-2). De aantallen nemen toe in de periode augustus/september, en vanaf maart nemen de aantallen weer af. Voor de Tureluur zien we een duidelijke najaarspiek in oktober, voor de overige drie soorten blijven de aantallen de gehele winterperiode hoog. In de maanden mei tot en met augustus zijn de aantallen in het telgebied laag.
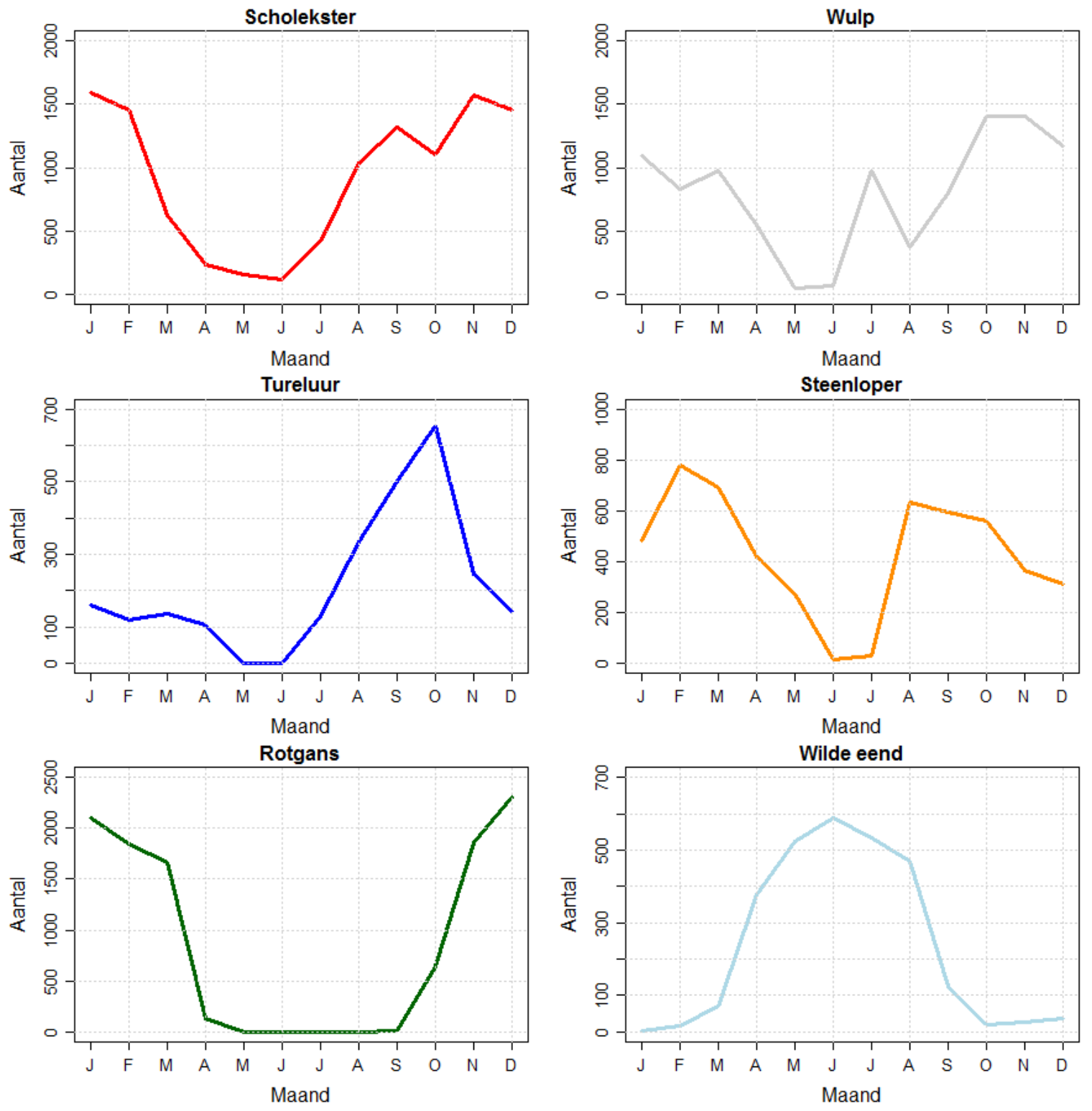

Figuur 3-2. Maandelijks verloop (gemiddeld over de periode 2010/2011 - 2014/2015) in het telgebied St. Pieterspolder (OS640).

\subsection{Veldbezoeken}

Naast het vaststellen van de huidige situatie zijn de veldbezoeken tevens gebruikt om na te gaan of de dijken buitendijks gebruikt worden als hoogwatervluchtplaats. Op alle dagen is vastgesteld dat verschillende soorten steltlopers, eendachtigen en meeuwen gebruik maken van de dijk als hoogwatervluchtplaats. Met name grote aantallen Scholeksters en Wulpen zijn waargenomen tijdens deze bezoeken (Figuur 3-3) ), alsmede Tureluur, Steenloper en enkele Zilverplevieren. Ook Wilde eenden, en enkele Smienten en Rotganzen zijn buitendijks op de dijkglooiing waargenomen, alsmede 
Kokmeeuwen. De plaatsen waar de vogels zich bevonden wisselde van dag tot dag en langs het hele tracé zijn overtijende groepen vogels waargenomen. De vogels bleken verstoringsgevoelig en vlogen snel op bij het oversteken van de dijk. Vooral de Wulpen bleken snel op te vliegen (Figuur 3-3).
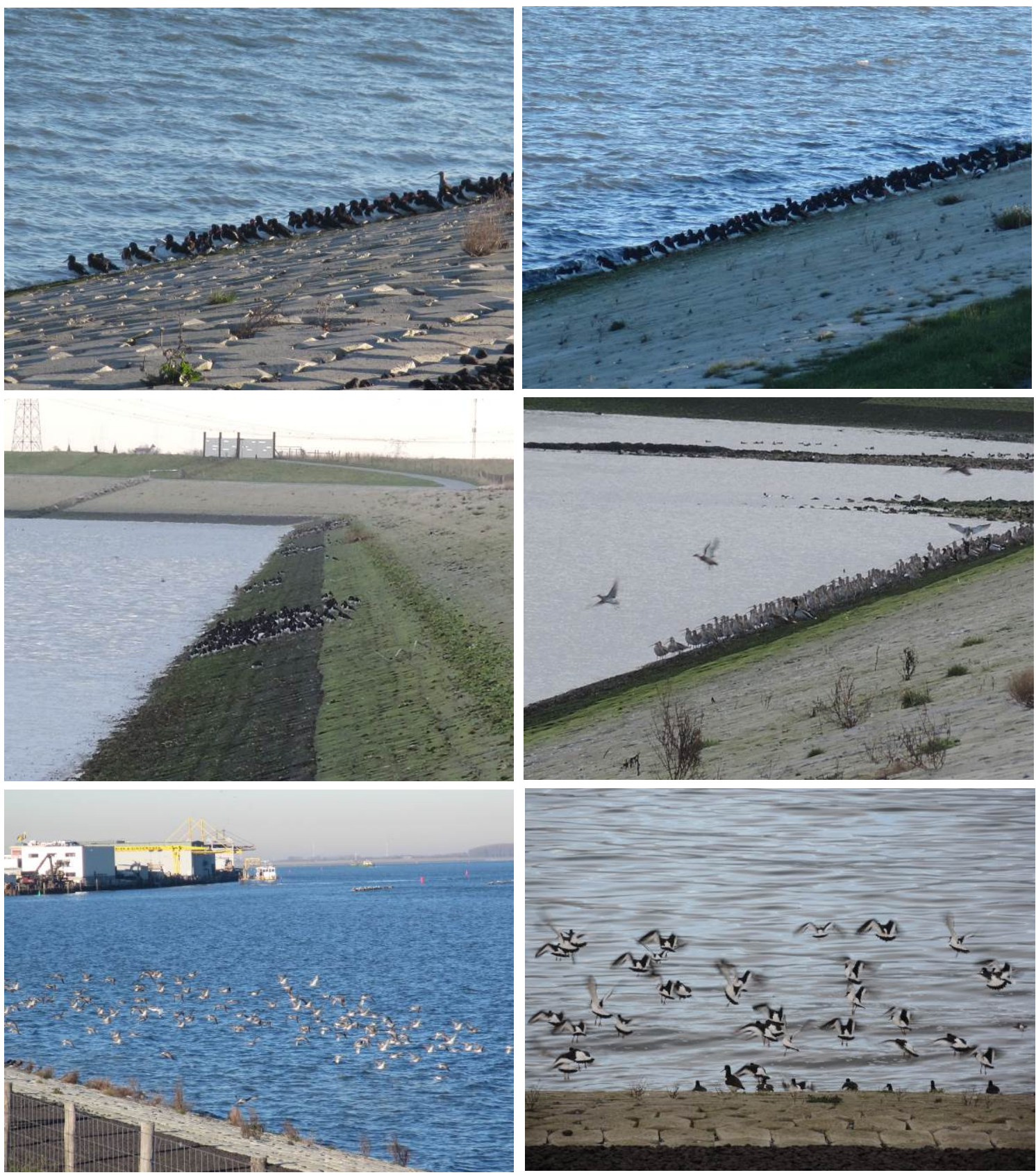

Figuur 3-3. Buitendijks overtijende steltlopers (vooral Scholeksters en Wulpen) en eenden langs het dijktracé van de Olzenepolder en Sint Pieterspolder tijdens de veldbezoeken. Foto's: Tom Ysebaert.

Dicht tegen Yerseke, nabij het kreeftenpark, bevindt zich in de hoek een klein strandje bezaaid met schelpen en stenen (puinstrandje Hardenhoek). Dit strandje blijkt een belangrijke hoogwatervluchtplaats te zijn, met name voor Tureluur, Steenloper en Scholekster. Tijdens alle bezoeken werden hier relatief grote aantallen van deze vogels aangetroffen (Figuur 3-4). 

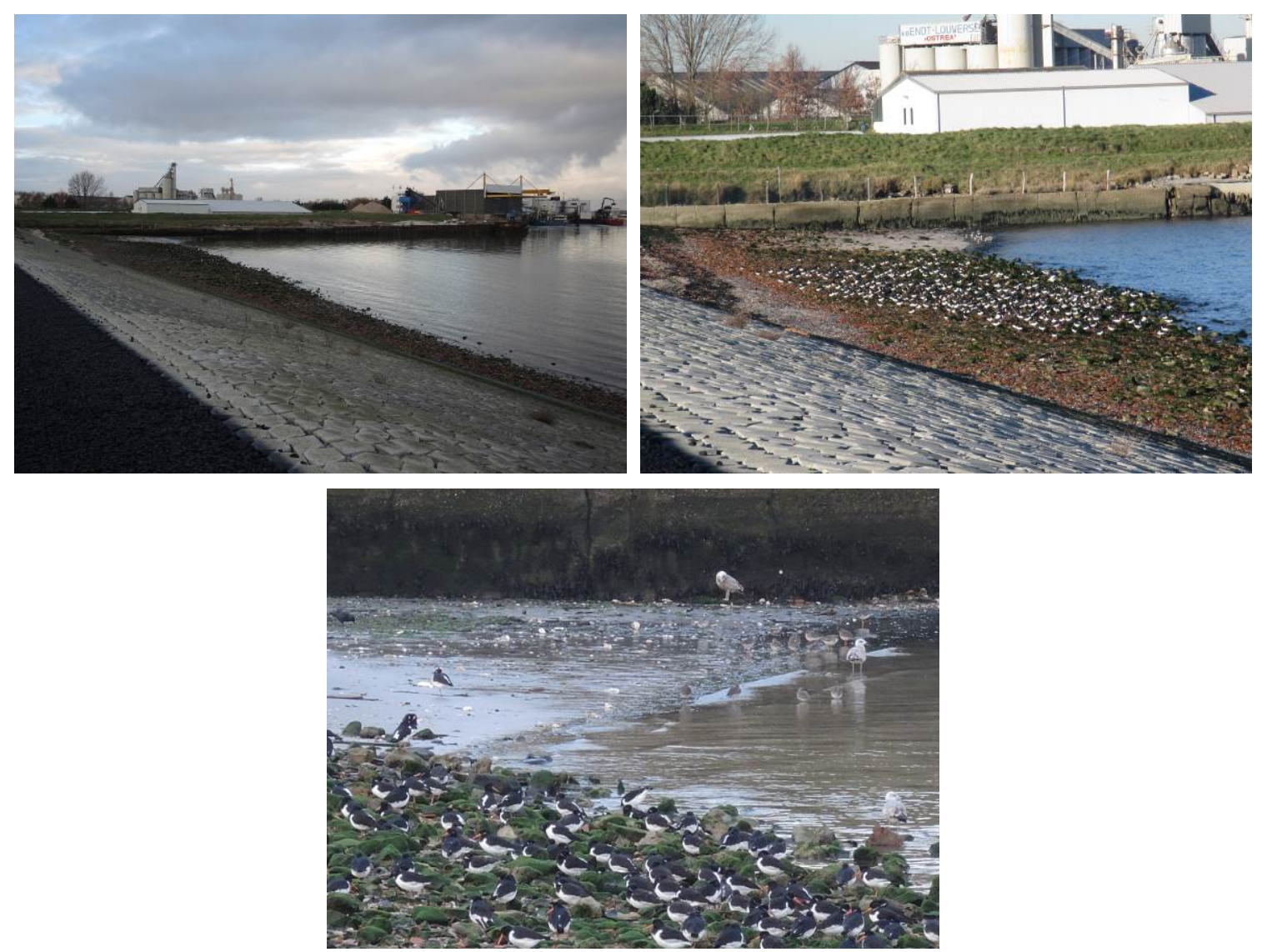

Figuur 3-4. Het strandje Hardenhoek. Op de stenen overtijen vooral Scholeksters en enkele Steenlopers, achterin op het slikje staat een groepje Tureluurs. Foto's: Tom Ysebaert.

Binnendijks op de weilanden en akkers overtijen ook vogels. Tijdens de veldbezoeken werden relatief grote aantallen Wulpen waargenomen, alsook Scholeksters (Figuur 3-5). De grootste aantallen steltlopers bevinden zich echter buitendijks langs de zeedijk. Grote aantallen Rotganzen komen ook voor, in de meeste gevallen foeragerend op de weilanden (Figuur 3-6). Omwille van de grotere afstanden van de weg tot de vogels is de verstoring duidelijk minder, hoewel vogels die dichter bij de weg zitten toch reageren op voorbijgangers (fietsers, wandelaars).

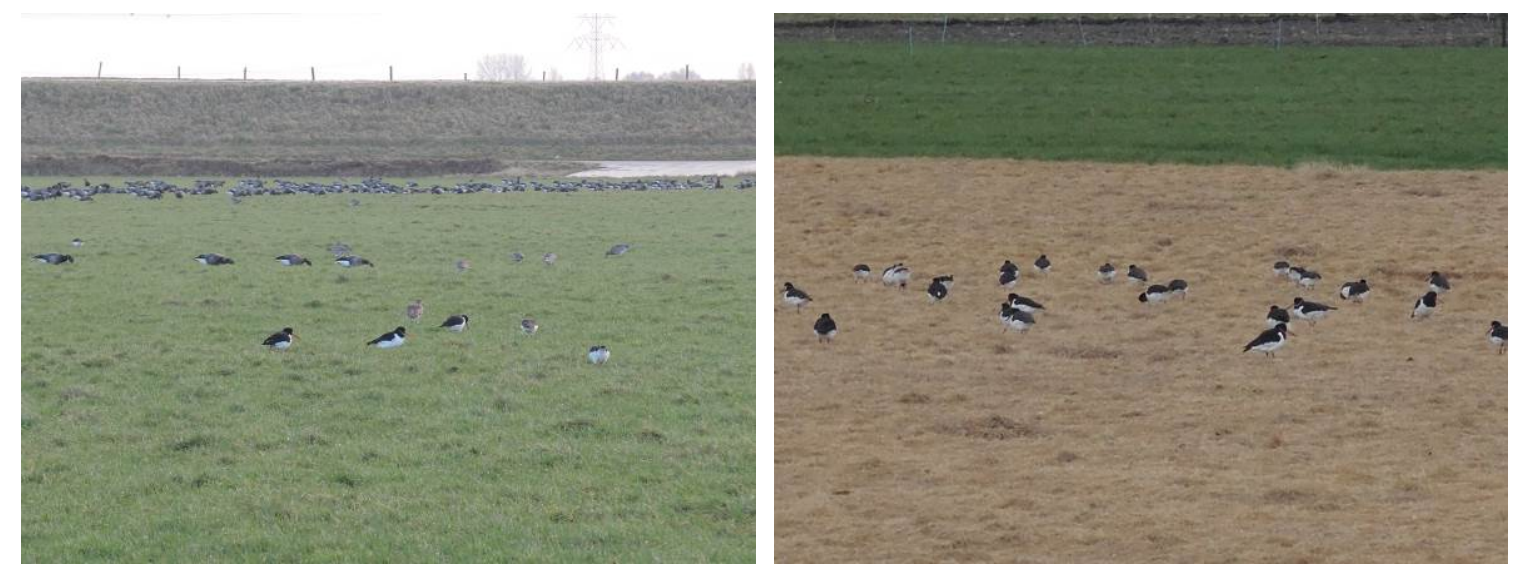

Figuur 3-5. Overtijende Scholeksters en Wulpen in de Sint Pieterspolder tijdens de veldbezoeken. Vaak zijn de vogels aan het foerageren. Foto's: Tom Ysebaert. 

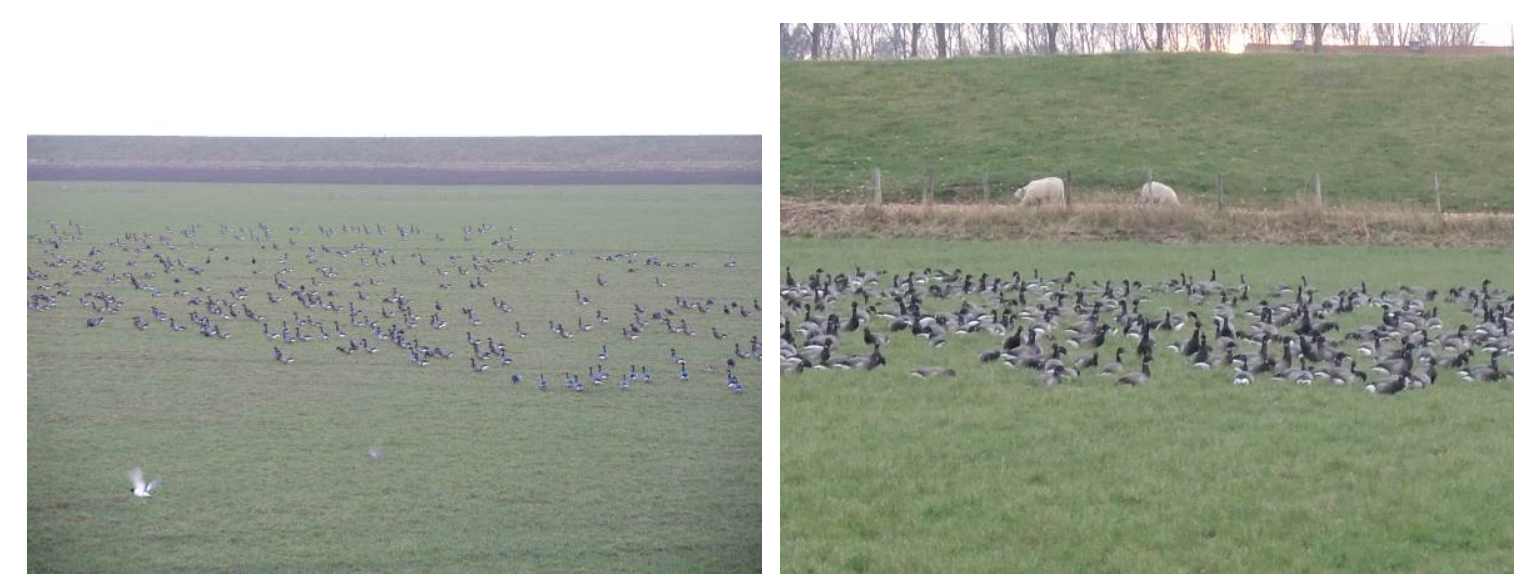

Figuur 3-6. Rotganzen in de Sint Pieterspolder tijdens de veldbezoeken. Foto's: Tom Ysebaert.

\subsection{Broedvogels}

De buitendijkse zijde van de zeedijk wordt sporadisch gebruikt door kustbroedvogels als broedgebied. Vooral de buitendijkse schelpen- en puinstrandjes in het gebied - vooral die in de hoek nabij Yerseke (Hardenhoek) - vormen een potentieel broedbiotoop voor kustbroedvogels als de Bontbekplevier (Wieland \& Vergeer 2010). Enkel broedgevallen van de Bontbekplevier langs het dijktracé worden vermeld door Strucker et al. (2014). In 2015 kwamen geen broedgevallen voor van de Bontbekplevier omwille van de dijkverzwaringswerken (Strucker et al. 2016). Tevens vermelden Strucker et al.

(2016) het kleiner worden van het puinstrandje bij Hardenhoek. Tijdens een broedvogelinventarisatie in 2010 werd tevens een Scholekster nest waargenomen op de zeedijk bij het oud landbouwhaventje (Wieland \& Vergeer 2010). 


\section{$4 \quad$ Conclusies en aanbevelingen}

Het buitendijkse dijktracé langs de Sint Pieterspolder en Nieuw Olzendepolder heeft een belangrijke functie als hoogwatervluchtplaats voor een aantal soorten steltlopers en eendachtigen. Met name Scholekster, Wulp, Tureluur, en in mindere mate Steenloper gebruiken de buitendijkse zijde van de zeedijk langs de Nieuw Olzendepolder en de St. Pieterspolder als hoogwatervluchtplaats. Ook Rotganzen en eenden als Wilde Eend, Pijlstaart en Smient gebruiken de dijk als hoogwatervluchtplaats. De grootste aantallen komen voor in de doortrekperiodes en de winter, in de periode april tot en met augustus zijn de aantallen in het gebied laag. De schelpen- en puinstrandjes langsheen het dijktracé vormen een potentieel geschikt habitat voor kustbroedvogels als de Bontbekplevier.

Buitendijks recreëren langsheen dit dijktracé leidt tot verstoring van de vogels die hier overtijen. Dit is duidelijk vastgesteld tijdens de veldbezoeken. Het zondermeer jaarrond openstellen van dit dijktracé voor fietsers is daarom niet aan te bevelen. Steltlopers hebben rust nodig en prefereren de zeedijk buitendijks als hoogwatervluchtplaats. Slechts een deel van de vogels gaat ook binnendijks zitten om te foerageren. Het landbouwgebied binnendijks is echter niet geschikt voor grote groepen overtijende steltlopers.

Wel is het voor recreanten op dit moment niet helemaal duidelijk wat wel en niet is toegestaan. Wandelaars lijken wel toegang te hebben tot het dijktracé, welke tot een gelijkaardige verstoring leidt als fietsen. Ook staan er aan de kant van Yerseke geen borden die aangeven dat er niet mag gefietst worden. Er staat wel een bareel die het niet mogelijk maakt om al fietsend de dijkovergang te betreden. Aan de kant van de Nieuwlandseweg, waar het buitendijkse fietspad dat van het oosten komt binnendijks wordt geleid, staat wel een duidelijk informatiebord met de reden waarom er ten westen van hier niet gefietst mag worden ("Fietsen en brommen niet toegelaten - Honden aan de lijn") (Figuur 4-1). De recreant wordt hier duidelijk geïnformeerd over de reden van deze maatregel, namelijk het voorkomen van verstoring van de hoogwatervluchtplaatsen voor watervogels. Men ziet ook dat het geasfalteerde fietspad overgaat in een minder uitnodigende wegbekleding om te fietsen. Wel wordt wandelen niet verboden, wat ook tot verstoring van de vogels kan leiden.

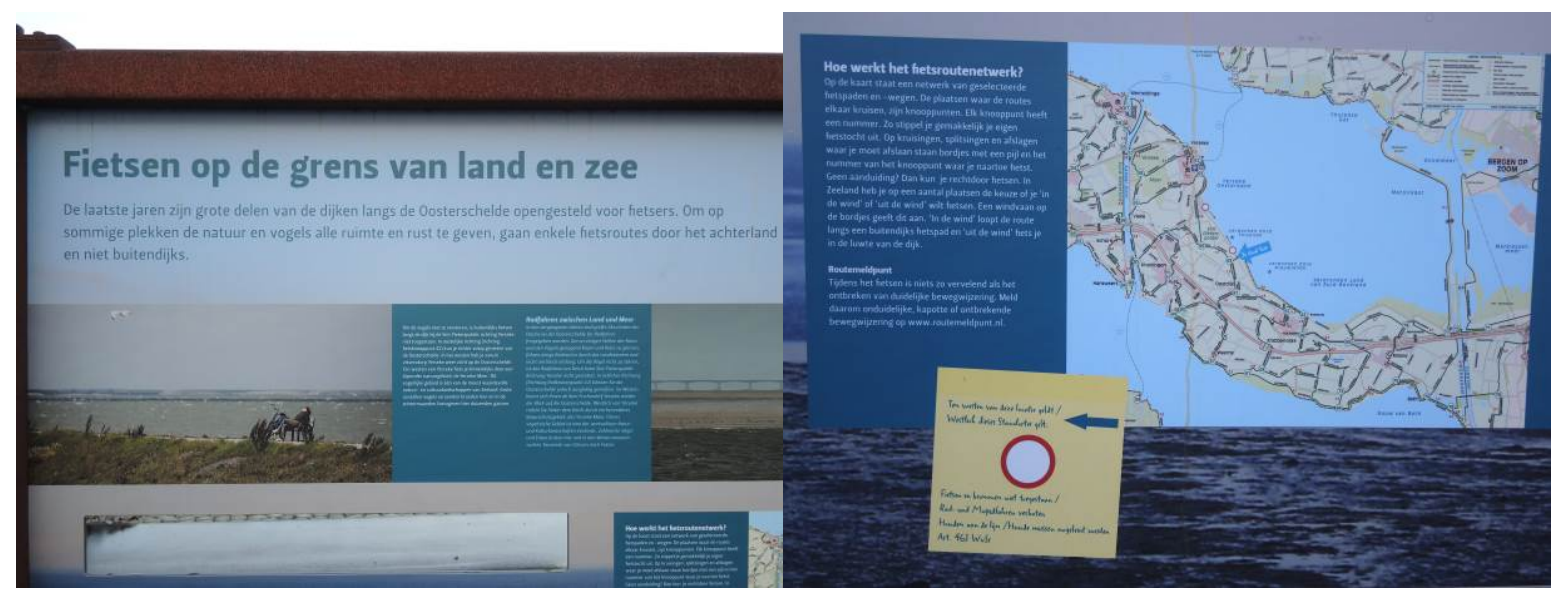

Figuur 4-1. Informatiebord nabij de Nieuwlandseweg die informatie verschaft over het fietsnetwerk langs de Oosterschelde en waarom er niet gefietst mag worden ten westen van dit bord. Foto's: Tom Ysebaert.

Om het gebied optimaler te benutten, met behoud en zelfs versterking van de natuurwaarde, zou een ruimtelijke en temporele zonering langsheen het dijktracé kunnen worden ingesteld, waarbij bepaalde trajecten volledig ontoegankelijk worden gemaakt (voor alle vormen van recreatie), en bepaalde trajecten toegankelijk worden gemaakt voor wandelaars en fietsers, zij het slechts gedurende een bepaalde tijd van het jaar, de zomerperiode tussen 1 april en 1 oktober. Wij stellen het volgende voor (Figuur 4-2): 
- Traject van de dijkovergang bij de Nieuw Olzendepolder tot Hardenhoek: buitendijks ontoegankelijk maken voor alle vormen van recreatie. Eventueel Hardenhoek inrichten als geschikt broedgebied voor kustbroedvogels. Mogelijk plaats voor een informatie- en vogelobservatiepunt.

- Traject van de dijkovergang bij de Nieuw Olzendepolder tot de dijkovergang bij het oude landbouwhaventje: buitendijks toegankelijk maken voor recreatie (wandelen en fietsen) gedurende de zomermaanden van 1 april tot 1 oktober. De overige periode van het jaar afsluiten voor alle vormen van recreatie. Het oude landbouwhaventje wordt hiermee toegankelijk tijdens de zomermaanden en het cultuurhistorisch aspect zou nader kunnen belicht worden via informatieborden. Tijdens de wintermaanden wordt het traject ontoegankelijk gemaakt voor recreatie waarbij de nodige informatie voorzien wordt.

- Traject van de dijkovergang bij het oude landbouwhaventje tot de Nieuwlandseweg: buitendijks ontoegankelijk maken voor recreatie. Hier wordt dus een stuk binnendijks gewandeld en gefietst, waarna terug aansluiting kan worden gemaakt met het buitendijkse fietspad richting het oosten. In dit traject zit wel een deel dat behoort tot een vergunde wormenspitlocatie (dijkpaal 1317 -1320). Het volledig vergunde traject voor wormenspitten bevindt zich tussen dijkpaal 1305 en 1320 en strekt zich dus meer naar het oosten uit. Men zou het traject dat open staat voor wormen spitten dus wat kleiner kunnen maken (dijkpaal 1305 - 1317), hoewel wormen spitten gebeurt bij laagwater en weinig verstoring veroorzaakt aan overtijende vogels.

Met deze zonering is de verwachting dat de natuurwaarden behouden blijven; door bepaalde trajecten volledig ontoegankelijk te maken (dus ook voor wandelaars), wordt verstoring hier zelfs verminderd. De recreant krijgt een gevarieerd aanbod van binnendijks en buitendijks recreëren, en heeft een meer directe aansluiting tot Yerseke. Naast infrastructurele aanpassingen zijn goede informatie, educatie en handhaving hierbij noodzakelijk, alsmede ook monitoring en evaluatie van de ingreep. Hierbij zal ook overleg met de plaatselijke landbouwer(s) dienen plaats te vinden.

Eventueel kunnen de trajecten uit Figuur 4-2 ook omgewisseld worden, waarbij het traject van de dijkovergang bij de Nieuw Olzendepolder tot de dijkovergang bij het oude landbouwhaventje jaarrond niet toegankelijk is, en het traject van de dijkovergang bij het oude landbouwhaventje tot de Nieuwlandseweg wel toegankelijk gemaakt wordt tijdens de zomermaanden (Figuur 4-3, Alternatief Traject 1). Hiermee wordt het traject dat buitendijks toegankelijk wordt gemaakt tijdens de zomermaanden wel korter. Om het oude landbouwhaventje te bereiken zullen extra voorzieningen getroffen moeten worden, omdat het haventje in dit alternatief niet langs de doorgaande fiets/wandelroute ligt. Wormenspitten wordt dan wel weer mogelijk (tijdens de zomermaanden of mits een extra regeling ook jaarrond, aangezien dit een laagwateractiviteit is).

Men zou kunnen overwegen om het buitendijkse traject uit Figuur 4-3 (Alternatief Traject 1) langer te maken (Figuur 4-4, Alternatief Traject 2), maar dit betekent dat een extra dijkovergang dient voorzien te worden. Waar die dan best komt moet nader onderzocht worden. Voordeel van dit alternatief is dat het oude landbouwhaventje langsheen de doorgaande route ligt. Ook in dit alternatief is dan wormenspitten nog mogelijk.

Het voordeel van het eerste traject (Figuur 4-2) is dat er twee gebieden jaarrond afgesloten worden, waardoor vogels uitwijkmogelijkheden hebben; in de twee alternatieve trajecten gaat het om slechts één gebied (Figuur 4-3, Figuur 4-4). Voor beide alternatieven (Alternatief Traject 1 en 2) geldt dan weer dat een groter deel van de dijk bij Hardenhoek jaarrond gesloten is in vergelijking tot het traject in Figuur 4-2; dit deel lijkt het belangrijkste deel te zijn voor buitendijks overtijende steltlopers (Arts 2015). Als mitigerende maatregel zou in de alternatieve trajecten de dijkovergang bij Hardenhoek kunnen worden weggehaald, waardoor hier risico op verstoring sterk afneemt. In alle voorstellen zijn maatregelen die het buitendijkse traject bij Hardenhoek aantrekkelijker maken voor overtijende watervogels en kustbroedvogels wenselijk. 


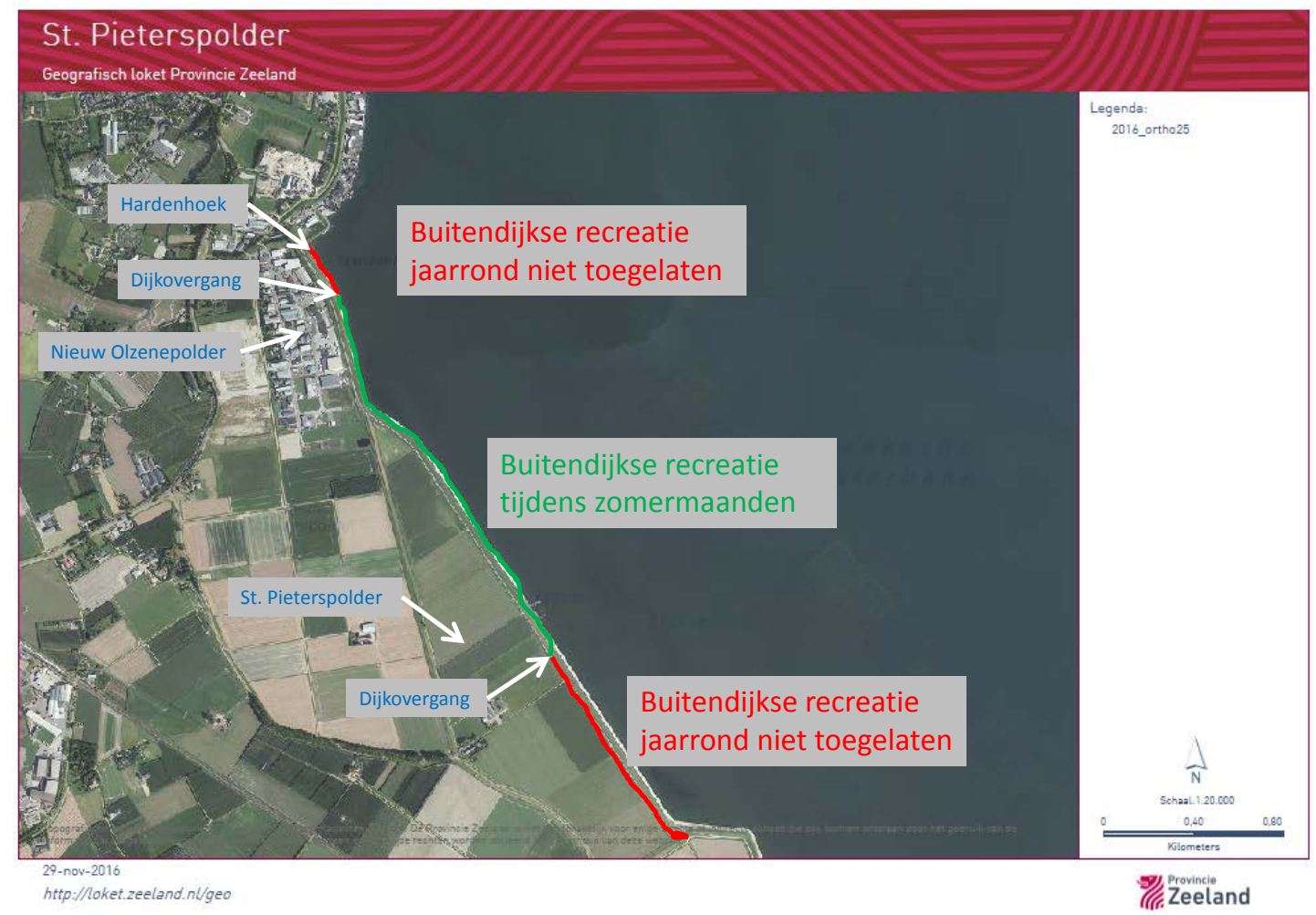

Figuur 4-2. Voorstel tot ruimtelijke en temporele zonering van het dijktracé langsheen de Nieuw Olzendepolder en St. Pieterspolder.

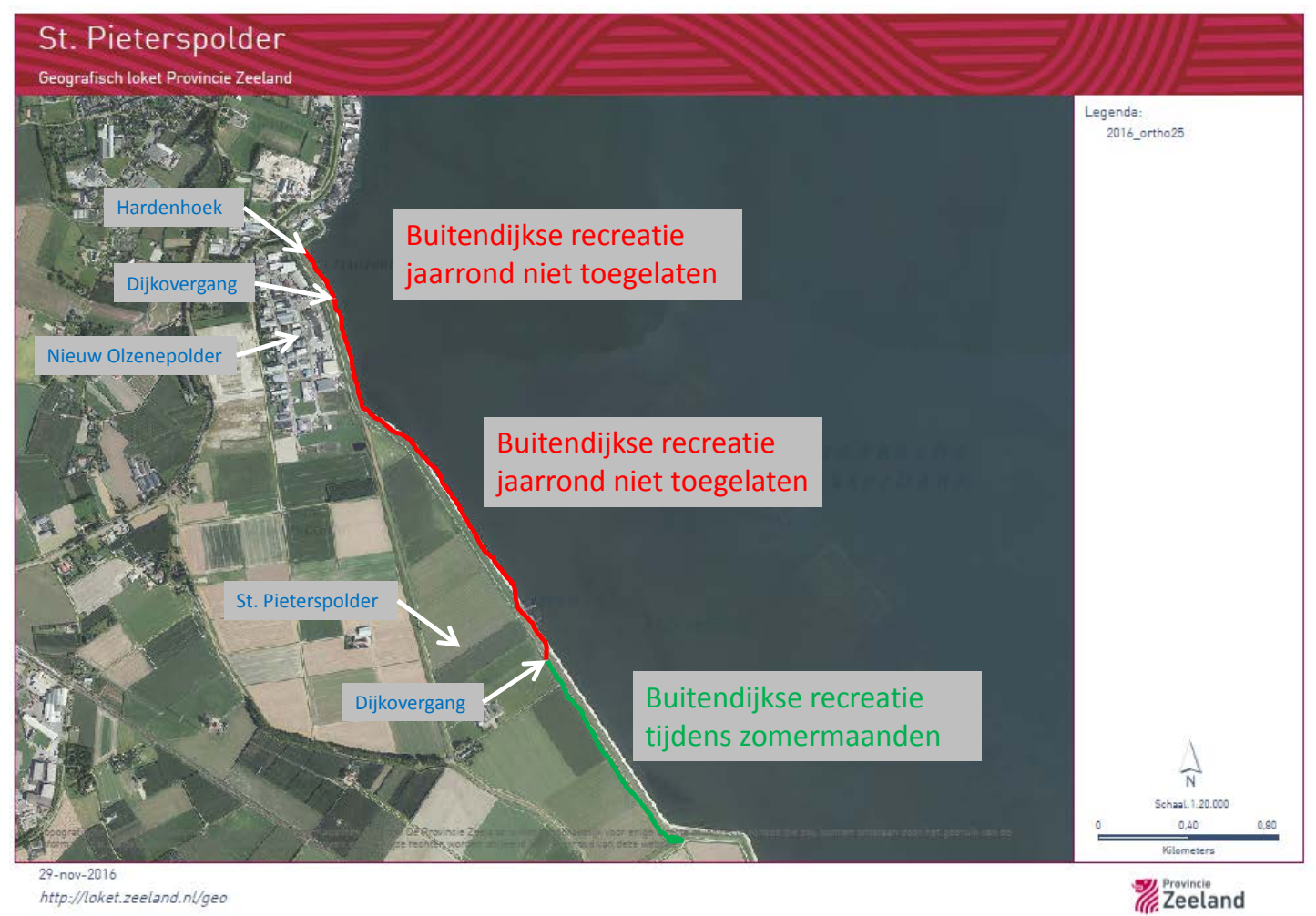

Figuur 4-3. Alternatief voorstel 1 tot ruimtelijke en temporele zonering van het dijktracé langsheen de Nieuw Olzendepolder en St. Pieterspolder. 


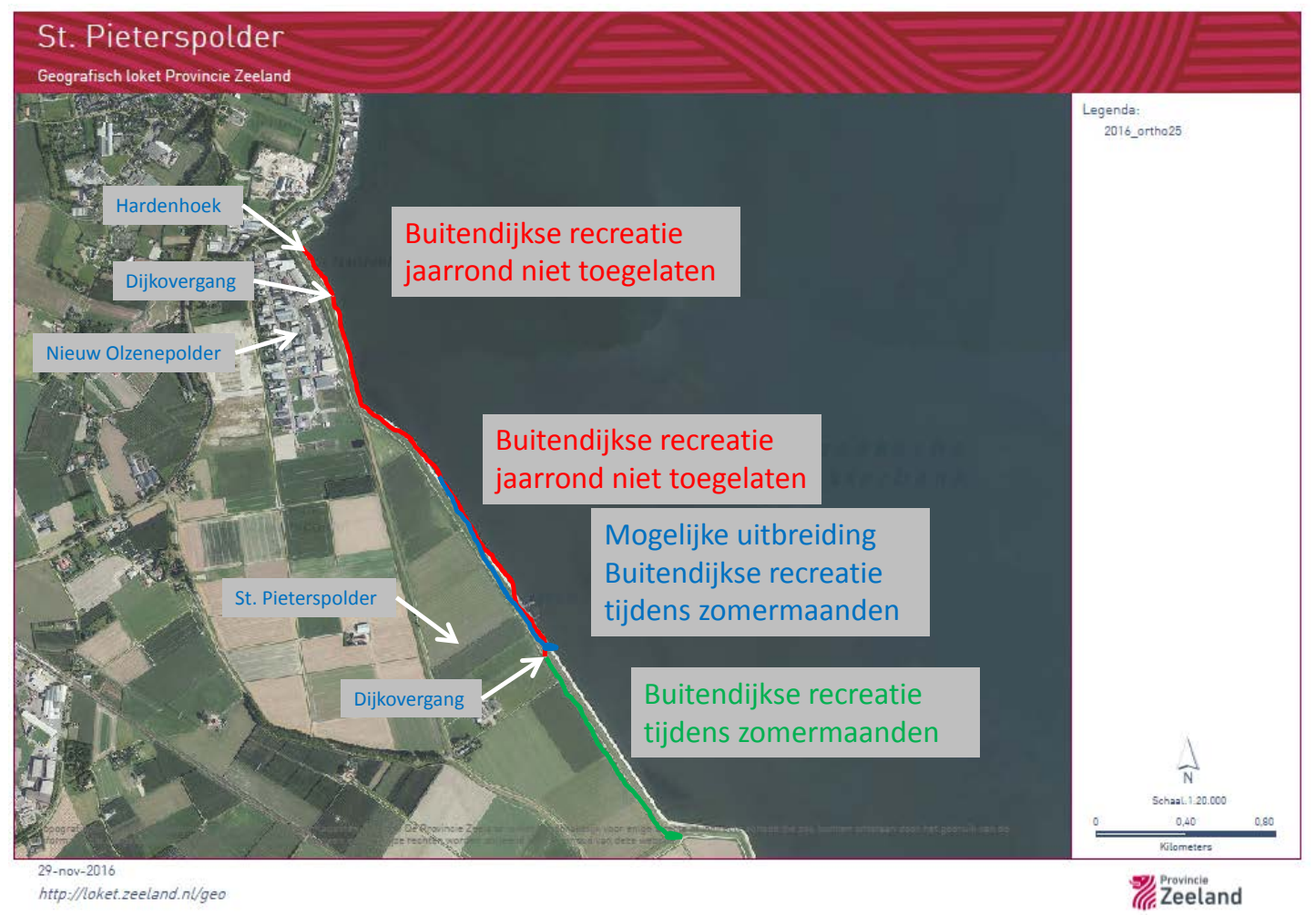

Figuur 4-4. Alternatief voorstel 2 tot ruimtelijke en temporele zonering van het dijktracé langsheen de Nieuw Olzendepolder en St. Pieterspolder. Bij openstelling van het blauwe traject dient een extra dijkovergang te worden gemaakt. 


\section{$5 \quad$ Kwaliteitsborging}

Wageningen Marine Research beschikt over een ISO 9001:2008 gecertificeerd kwaliteitsmanagementsysteem (certificaatnummer: 187378-2015-AQ-NLD-RvA). Dit certificaat is geldig tot 15 september 2018. De organisatie is gecertificeerd sinds 27 februari 2001. De certificering is uitgevoerd door DNV Certification B.V. 


\section{Literatuur}

Arts, F.A. 2015. Watervogels Zeedijk St Pieterspolder. Rapport Delta Project Management.

Arts F.A., S. Lilipaly and R.C.W. Strucker, 2016. Watervogels en zeezoogdieren in de Zoute Delta 2014 / 2015. RWS Centrale Informatievoorziening BM 16.09. Delta Project Management, Vlissingen Juni 2016. Gedownload op 25 november 2016 via: https:// www.deltamilieu.nl/uploads/other/BM-16.09-Watervogels-en-zeezoogdieren-in-deZoute-Delta-2014_2015.pdf

Ministerie van Infrastructuur en Milieu |Rijkswaterstaat, 2016. Natura 2000 Deltawateren, Beheerplan 2016-2022 Oosterschelde.

Schouten P., Krijgsveld K.L., Anema L.S.A., Boudewijn T.J. , van Horssen P.W., Reitsma J.M., Kuil R.E. \& Duijts H. 2005. Integrale beoordeling van effecten van dijkverbetering op de natuurwaarden van de Oosterschelde (IBOS). Rapport nr. 04-161. Bureau Waardenburg bv., Culemborg. Rijkswaterstaat Bouwdienst, Utrecht.

Strucker, R.C.W. et al. 2014. Kustbroedvogels in het Deltagebied in 2013. Delta Project Management: Vlissingen. $72+$ bijlagen pp.

Strucker, R.C.W. et al. 2016. Kustbroedvogels in het Deltagebied in 2015. Delta Project Management: Vlissingen. $39+$ bijlagen pp.

Wieland. A. \& Vergeer J-W. 2010. Broedvogels van de St. Pieterspolder - Nieuw Olzendepolder, alsmede een beeld van herpeto- en zoogdierfauna. SOVON-inventarisatierapport 2010/20. SOVON Vogelonderzoek Nederland, Nijmegen. 


\section{Verantwoording}

Rapport: C033/17

Dit rapport is met grote zorgvuldigheid tot stand gekomen. De wetenschappelijke kwaliteit is intern getoetst door een collega-onderzoeker en het verantwoordelijk lid van het managementteam van Wageningen Marine Research.

Akkoord:

Dr. Nathalie Steins

Handtekening:

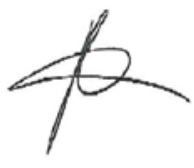

Datum:

7 april 2017

Akkoord:

Drs. Jakob Asjes

MT-lid integratie

Handtekening:

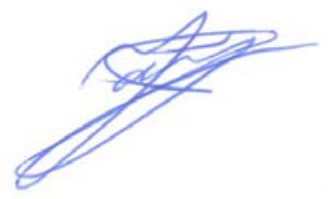

Datum:

7 april 2017 
Wageningen Marine Research

$\mathrm{T}:$ +31 (0)317 480900

E: marine-research@wur.nl

www. wur.nl/marine-research

Visitors address

- Ankerpark 271781 AG Den Helder

- Korringaweg 7, 4401 NT Yerseke

- Haringkade 1, 1976 CP IJ muiden
Wageningen Marine Research is the Netherlands research institute established to provide the scientific support that is essential for developing policies $\&$ innovation in respect of the marine environment, fishery activities, aquaculture $\&$ the maritime sector.

Wageningen University \& Research is specialised in the domain of healthy food \& living environment.

The Wageningen Marine Research vision:

'To explore the potential of marine nature to improve the quality of life.'

\section{The Wageningen Marine Research mission}

- To conduct research with the aim of acquiring knowledge $\&$ offering advice on the sustainable management $\&$ use of marine $\&$ coastal areas.

- Wageningen Marine Research is an independent, leading scientific research institute.

Wageningen Marine Research is part of the international knowledge organisation Wageningen UR (University \& Research centre). Within Wageningen UR, nine specialised research institutes of Stichting Wageningen Research (a Foundation) have joined forces with Wageningen University to help answer the most important questions in the domain of healthy food \& living environment. 